\title{
Is financial leverage mean-reverting? Unit root tests and corporate financing models
}

\author{
by \\ Maria Elena Bontempi and Roberto Golinelli*
}

First draft: January 16th, 2001

The present version: May 18th, 2001

JEL: $C 12, G 32, C 22, C 23$

\begin{abstract}
In this paper we use the unit root test at both individual company (Dickey-Fuller) and panel (Im-Pesaran-Shin) level, in order to provide some quantitative evidence of the univariate behaviour of Italian companies' debt-ratio. If it is mean-reverting, then at least a share of companies are going to behave according to the trade-off model, whereas if it is non-stationary, then companies may behave according to pecking order theory. Individual company test results support the pecking order theory in the case of more than $80 \%$ of firms, while the panel test rejects the unit root null. These contradictory results can be explained by the heterogeneity of the firms which tends to characterise the entire panel. For this reason, we selected a number of sub-samples in which companies are supposed to follow either the pure trade-off or the pure pecking order model of behaviour. Results confirm that: a) heterogeneity may lead to a false rejection of the pecking order theory in panel unit root tests; b) both trade-off and pecking order theories contribute towards explaining the financial behaviour of Italian companies; c) the testing procedure we propose has the power to reject the pure pecking order model under the null hypothesis, but not the pure trade-off model.
\end{abstract}

\footnotetext{
* Department of Economics, University of Bologna (Italy).E-mail: bontempi@ spbo.unibo.it ; golinell@spbo.unibo.it. Many thanks go to Gianni Amisano, Cheng Hsiao, Massimiliano Marcellino, Lucio Picci, Riccardo Rovelli, Antonello Scorcu and the participants at seminars held at the Universities of Bologna and Brescia for their useful comments and suggestions. The usual caveats apply.
} 


\section{Introduction}

Since the appearance of Nelson and Plosser's findings (1982) regarding a number of macroeconomic time series for the US, a significant percentage of recent empirical literature has been devoted to exploring the univariate properties of economic variables. Univariate outcomes are useful ways of characterising available data and preventing the researcher from producing spurious regressions (Granger and Newbold, 1974). Moreover, unit root outcomes may shed light on specific theories (see, for example, King, Plosser, Stock and Watson, 1991). In this paper, we propose to use unit root tests to obtain empirical evidence of the financial behaviour of Italian companies.

Theoretical literature on corporate finance presents two models. The trade-off theory (TO) (Bradley, Jarrell and Kim, 1984; Harris and Raviv, 1991) suggests that each firm has, or rather, particular classes of companies have, specific optimal debt-to-equity ratios, determined by balancing the present value of expected marginal benefits of leverage (for example, tax savings due to the deductibility of interest paid) against the present value of expected marginal costs of leverage (for example, default costs). According to TO theory, each company borrows in order to gradually move towards its optimal debt-equity ratio, which in turn maximises its market value (given by the present value of the sum of the expected costs and benefits of debt). Under plausible conditions, such as increasing marginal failure costs, the TO model presents a unique interior optimum capital structure for each type of company. If the current capital structure is perceived as optimal, then, unless perceptions change, the same capital structure will be viewed as optimal in future periods as well. Moreover, the cost of adjustment towards the target is not of primary concern in the TO model, and as such is rarely mentioned. This is why TO theory is also defined as "static TO theory".

The pecking order theory (PO) (Myers and Majluf, 1984) shows that, since investors are less informed about a firm's value than existing shareholders are, external financing may be mis-priced by the market: this under-pricing generates under-investment, i.e. the rejection of investment projects even if their net present values are positive. Thus the PO model suggests that firms adhere to a financial hierarchy in order to maximise their values: internal funds are given preference over external ones in financing investments; if external financing is needed, firms first seek debt funding, which is less subject to asymmetric information and lemon problems than new shares are; equity is only issued as a last resort, subsequent to stock price increases and/or when additional debt financing would be extremely costly because its value is affected by the revealing of managers' inside information. Unlike the TO model, therefore, the PO model does not envisage the existence of a target leverage: the debt-ratio is simply the sum of previous periodical hierarchical choices; retained earnings (internal equity) stand at the top of the hierarchy of preferences, while stock issues (external equity) lie at the bottom. Moreover, if riskless debt (the value of which is not affected by 
inside information, and which has no stock price effects) is available, firms never issue equity in a situation of extreme asymmetry of information; in this case, the PO theory requires an exogenous debt constraint.

From the empirical point of view, the TO hypothesis implies the assumption that the optimal debt-ratio is stable over time, and that the actual ratio fluctuates around it. On the basis of this mean-reverting property, the target is not estimated as a function of its determinants, but is measured using the historical mean of the actual debt-equity ratios (Taggart, 1977, Marsh, 1982, Jalilvand and Harris, 1984, Bradley, Jarrell and Kim, 1984, Opler and Titman, 1997, Shyam-Sunder and Myers, 1999). In the TO empirical model, the use of the historical mean of leverage minimises the effects of transient variations in time due to business cycles, flotation costs and companies' lagged adjustments towards their target debt-ratios. What is important is the long-term, average firm leverage (and not the determinants of periodical adjustment to the target debt-ratio), in order to decide whether the deviation from target of current debt-ratios, and the various leverage-related costs and benefits, are economically significant enough to influence the borrowing decisions of companies. The PO hypothesis empirically manifests itself in the form of a relationship between debt issues (or debt variations) and the availability of retained earnings.

Hence, unit root tests may provide empirical support for the predictions of TO and PO theories. In statistical terms, this issue can be tackled by answering the question of whether corporate debt-ratio time series are stationary or whether they exhibit a unit root. In the case of stationarity, the implicit mean-reverting behaviour suggests that companies gradually adjust towards an optimal and constant debt-ratio; in other terms, random shocks only have transitory effects on leverage. Thus the TO prediction works, and the use of the historical mean of leverage as a proxy for the target does not bias empirical results. Instead, the presence of unit roots is consistent with PO behaviour, where a well-defined optimal debt-ratio is lacking: debt changes are not driven by any attempt to attain an optimal capital structure, but simply reflect the need for external funds to finance investment projects. In other terms, random shocks, especially those pertaining to liquidity constraints, have a permanent effect on the financial structure of firms.

However, the presence of unit roots does not necessarily invalidate the TO model. In fact, the target debt-ratio itself may be unstable over time, as it may change according to changes in its non-stationary determinants, or to structural breaks. If some of the costs or benefits of borrowing vary, this may lead firms to structurally increase or decrease their reliance on corporate debt. If this is the case, we cannot use the sample period average to measure the target debt-ratio; instead, we have to estimate it as a function of its determinants (Bontempi, 2001). For this reason, unit root tests against a constant mean reversion have the power to reject the PO under the null, but the non- 
rejection of the null does not entail the rejection of the TO. Our result is consistent with that of Shyam-Sunder and Myers (1999) who, by assuming the behaviour of TO to be mean-reverting, and by using a different methodology, also show that "the target-adjustment models are not rejected even when false. The pecking order, when false, can be easily rejected. Thus our tests have the power with respect to the pecking order" (p. 242).

In this paper, we make time-series and panel unit root tests of company debt-ratios, measured as long and short-term debt to intermediaries (banks and other financial institutions such as factoring and leasing) on assets. Figures have been taken from a balanced panel of 5,079 Italian manufacturing companies over the 1982-1995 period, drawn from the Company Accounts Data Service data-set. Further information about data sources are available in Bontempi (2001).

The paper is arranged as follows. In section 2 we carry out the Dickey and Fuller (1979) unit root tests (DF and augmented DF, ADF) based on individual company debt-ratio time series. We use DF and ADF tests because they are comparable with the panel unit root test suggested by Im, Pesaran and Shin (1997) (IPS), that we performed in section 3. Given the discrepancy between the time series and panel unit root test results, we avoid extending the homogeneity of stationarity or non-stationarity proprieties to the whole panel. ${ }^{1}$ Instead, in section 4 , we carry out sub-panel unit root analyses, and compare results obtained in sub-samples selected on the basis of theoretical considerations such as homogeneous financial behaviour, with results obtained in randomly drawn sub-samples of companies. In section 5 we summarise the main results.

\section{The single-company unit root test}

Static TO behaviour may be formulated as the following target adjustment mechanism:

$$
\Delta d_{i t}=a_{i}\left(d_{i t-1}-d^{*}{ }_{i t}\right)+\varepsilon_{i t}
$$

where $d$ indicates the actual debt-ratio, $d^{*}$ is the target debt-ratio, and $\varepsilon$ is the stochastic error term. When parameter $a_{i}<0$, firms adjust towards the long-term target, although they may deviate from it in the short run. The target debt-ratio may be defined as follows:

[2] $\quad d^{*}{ }_{i t}=d^{*}{ }_{i}+u_{i t}$

where $d^{*}{ }_{i}$ is the specific firm's optimal debt-ratio, constant over time and determined by the tradeoff between the costs and benefits of borrowing; $u_{i t}$ is the zero mean stochastic component of the optimal leverage, which is stationary if the target is stable over time.

By substituting [2] in [1], we obtain:

\footnotetext{
${ }^{1}$ Karlsson and Lothgren (2000) analyse panel unit root test power using a number of Monte Carlo simulations, and advice caution when assessing the stationarity properties of data on the basis of panel unit root results only.
} 


$$
\Delta d_{i t}=c_{i}+a_{i} d_{i t-1}+v_{i t}
$$

where $c_{i}$ is the constant term whereby $d^{*}{ }_{i}=-c_{i} / a_{i} ; v_{i t}=\varepsilon_{i t}-a_{i} u_{i t}$ depends on both the error of equation [1] and the stochastic component of equation [2]. The general formulation of equation [3] is as follows:

[4] $\quad \Delta d_{i t}=c_{i}+\pi_{i} d_{i t-1}+\sum_{j=1}^{p} \tilde{a}_{i j} \Delta d_{i t-j}+v_{i t}$

If we suppose that both $\varepsilon$ and $u$ are white noise processes, then $p=0$ and equation [4] reduces to the DF unit root test model for the $i^{\text {th }}$ firm as in equation [3]. In the case of more complex dynamics of $\varepsilon$ and/or $u$, we have to set $p>0$ until $v$ is a white noise process (ADF test equation).

For each of the 5,079 companies in our balanced 1984 - 1995 panel we performed both DF and $\operatorname{ADF}(1)^{2}$ tests: the null is $\pi_{i}=0$, i.e. the debt-ratio stochastic process for the $i^{\text {th }}$ firm has a unit root; under the alternative, $\pi_{i}<0$, i.e. the $i^{\text {th }}$ company leverage is mean-reverting. The estimated probability density function of the DF statistics is presented in figure 1; in order to improve readability, we trimmed the distribution at $2 \% .^{3}$

Fig. 1 - Distribution of 5,079 individual DF statistics

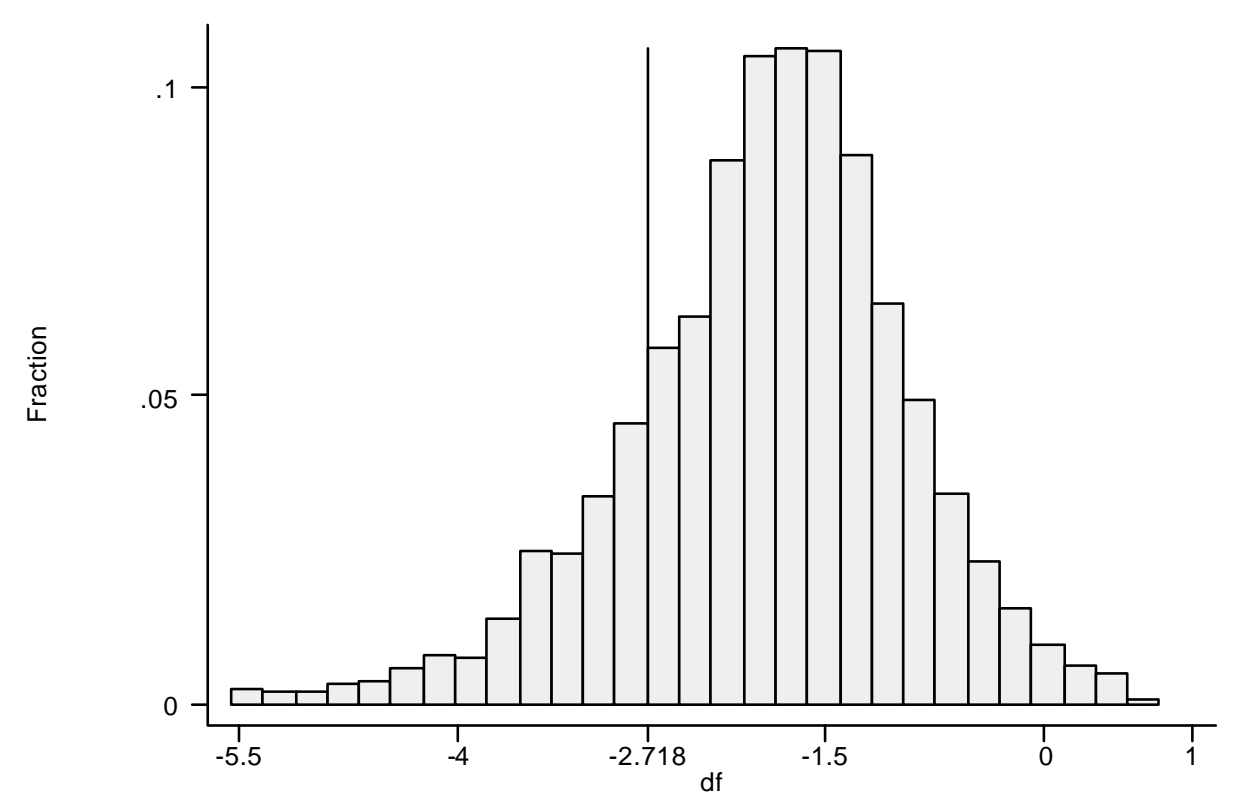

The vertical line represents the $10 \%$ critical value of the test (equal to -2.718 from MacKinnon, 1991): for about $82 \%$ of the cases the null is not $10 \%$ rejected, leading to a strong

\footnotetext{
${ }^{2}$ Given the limited time span, we prefer to avoid longer lags; moreover, dealing with annual data, a second order autoregressive dynamic should be enough to avoid residual serial correlation. The first two years (1982-1983) are used for the initialisation of the dynamic process.

${ }^{3}$ The density of ADF statistics is not plotted, as it is almost identical to the DF one.
} 
presumption in favour of unit roots. ${ }^{4}$ On the basis of individual company test results, we could conclude that in a large number of cases, Italian manufacturing firms do not seem to be driven by a constant debt-ratio target, but behave in line with PO theory.

Previous results may depend either on low speeds of adjustment $\left(\pi_{i}\right)$ of actual to target debtratios, or on high standard errors in their estimation. On the basis of $\pi_{i}$ estimates corresponding to DF statistics in Figure 1, we calculated that about one year is necessary for the median company to close half of the deviation between actual and target debt-ratios. ${ }^{5}$ This adjustment period seems quite short compared with our time span of 12 years. Since one relevant factor in unit root testing is the length of the time span compared to the length of the period for which data is available (Hakkio and Rush, 1991), a 1984-1995 sample period might be sufficient enough for our purposes.

Thus, the precision of $\pi_{i}$ estimates might be the main problem we have with our DF test results. In order to tackle this issue, in the next section we perform panel unit root tests: the advantage in doing so is that, since the power of the tests depends on the total variation in the data used (both in the number of observation and their variability), the cross-section variation adds information to time series variability, and leads to potentially more precise parameter estimates (Taylor and Sarno, 1998, p. 283). A formal demonstration of the fact that exploiting cross-sectional as well as time-series variability may increase the power of unit root tests, can be found in Levin and Lin (1992).

\section{The panel unit root test}

Since the seminal work of Hakkio (1984), a significant number of papers have been devoted to the test of the purchasing power parity hypothesis within the panel framework. ${ }^{6}$ However, research has not been addressed to the exchange rate issue alone, and the time series properties of many macroeconomic variables have also been extensively investigated at panel level. ${ }^{7}$ Banerjee, Marcellino and Osbat (2001) warn of the validity of test results regarding macroeconomic variables

\footnotetext{
${ }^{4}$ Detailed results are available upon request.

${ }^{5}$ The first quartile is slightly less than 8 months; the third quartile is about 2 years.

${ }^{6}$ These include: Frankel and Rose (1996), Higgins and Zakrajsek (1999), MacDonald (1996), O’Connell (1998), Oh (1996), Papell (1997), and Wu (1996).

${ }^{7}$ For example, the properties of the real GDP of 48 US states were analysed by Strauss (2000), the inflation rate for 13 OECD countries by Culver and Papell (1997), the price indices for 19 US cities by Cecchetti, Mark and Sonora (2000), the current account per output for 10 OECD countries by Wu (2000), the unemployment rate for 48 US states by Song and Wu (1997) and for US states and EU countries by León-Ledesma (2000), the interest rate for 12 OECD countries by Wu and Zhang (1996).
} 
for several countries if potential cross-unit cointegration does in fact exist. ${ }^{8}$ We think this criticism is less stringent in our case, since we use more than 5,000 microeconomic 12 -year time series for companies, and cross-company debt-ratio co-movements are not so obvious as in the case of countries.

A number of unit root/stationarity panel tests can be found in the literature: the LL test (Levin and Lin 1992, 1993), the $\mathrm{Z}_{\mu}$ test (Hadri, 2000), and the IPS $t$-bar test (Im, Pesaran and Shin, 1997). A limit of the unit root LL test, as noted by Maddala and Wu (1999, p. 635), is the restriction $\pi_{i}=\pi, \forall i$ : all the individual autoregressive parameters are supposed to be the same under both the null hypothesis and its alternative. In our case, it is quite unrealistic to suppose that under the alternative hypothesis each company's debt-ratios revert to their respective unconditional means at the same rate. The stationarity $\mathrm{Z}_{\mu}$ test is applicable to panel data with large $\mathrm{T}$ and moderate $\mathrm{N}$. In fact, in order to derive the asymptotic distribution of the test statistic, Hadri (2000, p. 152) follows a sequential limit approach $(\mathrm{T} \rightarrow \infty$ followed by $\mathrm{N} \rightarrow \infty)$ that is justified in a situation where the panel data set has many more time series components than cross-section components. Since we have $\mathrm{T}=12$ and $\mathrm{N}=5079$, it is clear that the $\mathrm{Z}_{\mu}$ test is inappropriate for our panel data set.

Therefore, the most suitable test in our case is the IPS one. In fact, it relaxes the assumption that all autoregressive parameters are the same for all individuals; moreover, the IPS statistic is valid as $\mathrm{T}$ and $\mathrm{N} \rightarrow \infty$. IPS perform $\mathrm{N}$-independent $\mathrm{DF}$ tests on the significance of the parameter $\pi$ in equation [4]. By using Monte Carlo methods in the case of balanced panels, IPS tabulate the first, $\mathrm{E}\left(t_{i, T}\right)$, and the second, $\mathrm{V}\left(t_{i, T}\right)$, moments of the DF (and ADF) statistics $\left(t_{i, T}\right)$, and show that:

$$
\sqrt{\mathrm{N}} \frac{\overline{\mathrm{t}}_{\mathrm{N}, \mathrm{T}}-\mathrm{E}\left(\mathrm{t}_{\mathrm{i}, \mathrm{T}}\right)}{\sqrt{\mathrm{V}\left(\mathrm{t}_{\mathrm{i}, \mathrm{T}}\right)}} \Rightarrow \quad(0,1) \quad \text { where: } \overline{\mathrm{t}}_{\mathrm{N}, \mathrm{T}}=\frac{1}{\mathrm{~N}} \sum_{\mathrm{i}=1}^{\mathrm{N}} \mathrm{t}_{\mathrm{i}, \mathrm{T}}
$$

Under the null hypothesis of the IPS test, all the $\mathrm{N}$ individual time series have a unit root:

[6] $\quad \pi_{\mathrm{i}}=0 \quad \forall \mathrm{i}$

while under the alternative hypothesis they are grouped into two complementary sets: $\mathrm{N}_{\mathrm{S}}$ of nonstationary processes, and $\mathrm{N}_{1-\mathrm{S}}$ of stationary processes:

$$
\pi_{\mathrm{i}}=0 \quad \forall \mathrm{i} \in \mathrm{N}_{\mathrm{S}}
$$

$$
\pi_{\mathrm{i}}<0 \quad \forall \mathrm{i} \in \mathrm{N}_{1-\mathrm{S}}
$$

The results of IPS tests for Italian firms are given in Table 1; trimmed means are also given in order to check the sensitiveness of the results to the presence of outliers.

\footnotetext{
${ }^{8}$ By using a set of Monte Carlo experiments, they show that "The empirical size of the tests is substantially higher than the nominal level, so that the null hypothesis of a unit root is rejected very often, even if correct.” (p. 1).
} 
The results always reject the unit root under the null hypothesis: the full sample t-bar statistic and the trimmed averages are lower than both the exact 1\% sample critical values (more reliable), and those critical values obtained using simulated moments and asymptotic standard normal percentiles. Outcomes are also robust to the specification of error dynamics (DF and ADF tests). The slight increase in $\mathrm{ADF}$ test statistics results from partial inefficiency due to the introduction of sometimes-unnecessary dynamics. In fact, following Campbell and Perron (1991) suggestion of leaving lags whose corresponding estimates are $10 \%$ significant, the augmentation is only significant in $16.8 \%$ of cases.

Finally, in order to take account of the potential dependence among individuals, together with the influence of macroeconomic shocks, we subtract the cross-sectional mean of the debt-ratio of each period, and then we apply the IPS test to the transformed data. The outcome remains much the same: the unit root null is rejected.

Tab. 1 - t-bar tests over different trimming options and time effects

\begin{tabular}{lccc}
\hline Average & Number of firms & $D F$ & $A D F(1)$ \\
\hline \multicolumn{4}{c}{ Levels: } \\
Full sample mean & 5079 & -1.950 & -1.708 \\
$2 \%$ trim & 4978 & -1.894 & -1.764 \\
$10 \%$ trim & 4573 & -1.871 & -1.745 \\
$20 \%$ trim & 4066 & -1.856 & -1.735
\end{tabular}

Deviations from cross-sectional averages (demeaned):

$\begin{array}{llll}\text { Full sample mean } & 5079 & -1.922 & -1.800 \\ 2 \% \text { trim } & 4978 & -1.899 & -1.780 \\ 10 \% \text { trim } & 4573 & -1.870 & -1.755 \\ 20 \% \text { trim } & 4066 & -1.853 & -1.743\end{array}$

$\begin{array}{lccc}\text { exact sample }\left(^{*}\right) & - & -1.740(-1.670) & - \\ \operatorname{asymptotic}\left({ }^{* *}\right) & - & -1.545(-1.536) & -1.536(-1.526)\end{array}$

( ${ }^{*}$ Im, Pesaran and Shin (1997), Table 4; T=15, N=100

${ }^{* * *}$ ) Authors calculations from Im, Pesaran and Shin (1997), Table 2; T=15

It is often claimed that the panel framework of the unit root test provides greater power than the individual time series unit root test (Oh, 1996, p. 413). Thus, if conflicting results are obtained from individual and panel unit root tests, we should have more faith in the panel results because of their greater power. Previous results could lead us to conclude that a sizeable subgroup of Italian companies has a long-term target debt-ratio that can be proxied by the sample mean, as predicted by TO. 


\section{Unit roots and heterogeneity}

The main failing of panel unit root tests is that the null hypothesis (usually that all the series in the panel are realisations of unit root processes) will be violated even if a very small number of series in the panel are stationary, and rejection cannot help us calculate the entity of that number (Taylor and Sarno, 1998, p. 283). In empirical studies of panel unit root tests, really extreme cases are reported. In $\mathrm{Wu}(2000)$ the unit root null is 5\% rejected even though the only case (at the individual level) of a stationary process is excluded from the panel. These results confirm Culver and Papell (1997) findings concerning the fragility of the non-rejection of the unit root null hypothesis in the presence of cross-section variation, while mixed results are reported in LeónLedesma (2000).

Previous findings raise the question of how much cross-section variation is necessary in order to reject a unit root in debt-ratio data. Henceforth, we will attempt to understand whether the IPS test rejection of the null hypothesis is due to its higher power compared with the individual company DF tests, or whether it is due to its mixed specification of the alternative in presence of behavioural heterogeneity. Thus, in this section we carry out IPS tests at an intermediate level of firm pooling, i.e. in sub-samples chosen on a priori theoretical grounds. Our intention is to identify the $\mathrm{N}_{\mathrm{S}}\left(\mathrm{N}_{1-\mathrm{S}}\right)$ set defined in [7] as the theory-based sub-sample homogeneously characterised by PO (TO) behaviour. In this way, testing for pure PO financing is performed by using the statistic $\overline{\mathrm{t}}_{\mathrm{N}_{\mathrm{S}}, \mathrm{T}}=\frac{1}{\mathrm{~N}_{\mathrm{S}}} \sum_{\mathrm{i}=1}^{\mathrm{N}_{\mathrm{S}}} \mathrm{t}_{\mathrm{i}, \mathrm{T}}$ on:

[6'] $\quad \mathrm{H}_{0}: \pi_{\mathrm{i}}=0 \quad \forall \mathrm{i} \in \mathrm{N}_{\mathrm{S}}$

against

$$
\text { [7'] } \quad \mathrm{H}_{1}: \pi_{\mathrm{i}}<0 \quad \forall \mathrm{i} \in \mathrm{N}_{\mathrm{S}}
$$

Testing for pure TO financing is performed by using the statistic $\overline{\mathrm{t}}_{\mathrm{N}_{1-\mathrm{S}}, \mathrm{T}}=\frac{1}{\mathrm{~N}_{1-\mathrm{S}}} \sum_{\mathrm{i}=1}^{\mathrm{N}_{1-\mathrm{S}}} \mathrm{t}_{\mathrm{i}, \mathrm{T}}$ on:

[6"] $\quad \mathrm{H}_{0}: \pi_{\mathrm{i}}=0 \quad \forall \mathrm{i} \in \mathrm{N}_{1-\mathrm{S}}$

against

[7'] $\quad \mathrm{H}_{1}: \pi_{\mathrm{i}}<0 \quad \forall \mathrm{i} \in \mathrm{N}_{1-\mathrm{S}}$

Two points need to be made here. Firstly, homogeneity under both the null hypothesis [6'] ([6"]) and the alternative one [7'] ([7'] $)$ is valid if we are able to correctly identify $\mathrm{N}_{S}\left(\mathrm{~N}_{1-\mathrm{S}}\right)$ as the pure PO (TO) behaviour sub-sample. Secondly, selection rules used to distinguish between $\mathrm{N}_{\mathrm{S}}$ and $\mathrm{N}_{1-\mathrm{S}}$ are based on the determinants of internal financing and the target leverage suggested by PO and TO theories; in this way, we introduce elements of multivariate analysis into the context of univariate unit root tests. 


\subsection{The IPS test results in theory-based sub-samples}

We identified four types of $\mathrm{N}_{\mathrm{S}}$ and $\mathrm{N}_{1-\mathrm{S}}$ sub-samples: risk, tax exhaustion, managerial and creditors' agency costs. The $\mathrm{N}_{1-\mathrm{S}}$ (TO) sets correspond, respectively, to "low" risk, tax exhaustion and creditors" agency costs, and to "high" managerial agency costs; the $\mathrm{N}_{\mathrm{S}}$ (PO) sets are symmetrically defined as those in which there are no determinants of the target leverage. Detailed information about the selection rules of the theory-based sub-samples is given in the appendix, while test results are shown in Table 2.

The first type of theory-based sub-sample involves the probability and costs of bankruptcy (Castanias, 1983). As is the practice in empirical financial studies, failure risk is assessed by some measure of the volatility of interest costs compared to earnings before interest charges: firms with more volatile interest expenses may find themselves more often in the situation where earnings are too low for debt servicing (thus implying a higher credit risk). The higher bankruptcy costs are, the greater the effect of default risk: firms with no guarantees and proportionately fewer tangible assets, which can be used as collateral, have higher liquidation costs. The results given in Table 2 show that the unit root null hypothesis is rejected in the "low risk" (TO) sub-sample of companies with a low likelihood of distress and a high liquidation value. These firms can behave according to the TO model because banks specialise in lending to companies with low credit risk and bankruptcy costs.

Tab. 2 - t-bar tests in alternative sub-samples

\begin{tabular}{|c|c|c|c|c|c|}
\hline Sub-sample definition & $\begin{array}{l}\text { Number } \\
\text { of firms }\end{array}$ & $D F$ & $A D F(1)$ & $D F$ & $A D F(1)$ \\
\hline & & \multicolumn{2}{|c|}{ Levels: } & \multicolumn{2}{|c|}{ Demeaned: } \\
\hline $\begin{array}{l}\text { High risk }\left(\mathrm{N}_{\mathrm{S}}\right) \\
\text { Low risk }\left(\mathrm{N}_{1-\mathrm{S}}\right)\end{array}$ & $\begin{array}{l}106 \\
367\end{array}$ & $\begin{array}{l}-1.512 \\
-2.345^{* * *}\end{array}$ & $\begin{array}{l}-1.496 \\
-2.136\end{array}$ & $\begin{array}{l}-1.615 \\
-2.157^{* * *}\end{array}$ & $\begin{array}{l}\mathbf{- 1 . 5 7 0} \\
-1.924^{* * *}\end{array}$ \\
\hline $\begin{array}{l}\text { High tax exhaustion }\left(\mathrm{N}_{\mathrm{S}}\right) \\
\text { Low tax exhaustion }\left(\mathrm{N}_{1-\mathrm{S}}\right)\end{array}$ & $\begin{array}{l}126 \\
111\end{array}$ & $\begin{array}{l}-1.571 \\
-2.845\end{array}$ & $\begin{array}{l}-1.524 \\
-\mathbf{2 . 7 2 3}^{* * *}\end{array}$ & $\begin{array}{l}-1.619 \\
-2.300^{* * *}\end{array}$ & $\mathbf{- 2 . 0 9 3}^{* * * *}$ \\
\hline $\begin{array}{l}\text { Low managerial agency costs }\left(\mathrm{N}_{\mathrm{S}}\right) \\
\text { High managerial agency costs }\left(\mathrm{N}_{1-\mathrm{S}}\right)\end{array}$ & $\begin{array}{l}53 \\
25\end{array}$ & $\begin{array}{l}-1.565 \\
-2.488\end{array}$ & $\begin{array}{l}-\mathbf{1 . 3 6 6} \\
-2.185^{* * *}\end{array}$ & $\begin{array}{l}-\mathbf{1 . 5 7 3} \\
-2.236^{* * *}\end{array}$ & $\begin{array}{l}\mathbf{- 1 . 3 5 1} \\
-2.082^{* * *}\end{array}$ \\
\hline $\begin{array}{l}\text { High creditors' agency costs }\left(\mathrm{N}_{\mathrm{S}}\right) \\
\text { Low creditors' agency costs }\left(\mathrm{N}_{1-\mathrm{S}}\right)\end{array}$ & $\begin{array}{l}75 \\
167\end{array}$ & $\begin{array}{l}\mathbf{- 1 . 5 1 0} \\
-1.949^{* * *}\end{array}$ & $\begin{array}{l}\mathbf{- 1 . 4 2 1} \\
-1.772^{* * *}\end{array}$ & $\begin{array}{l}-\mathbf{1 . 5 6 5} \\
-1.940^{* * *}\end{array}$ & $\begin{array}{l}\mathbf{- 1 . 4 7 3} \\
-1.805^{* * *}\end{array}$ \\
\hline $\begin{array}{l}\text { Random samples: } \\
\text { lower } 95 \% \text { bound } \\
\text { upper } 95 \% \text { bound }\end{array}$ & $\begin{array}{l}300 \\
300\end{array}$ & $\begin{array}{l}-2.159^{* * * *} \\
-1.799^{* * *}\end{array}$ & $\begin{array}{l}-2.072^{* * *} \\
-1.665^{*}\end{array}$ & $\begin{array}{l}-2.046^{* * *} \\
-1.807^{* * *}\end{array}$ & $\begin{array}{l}-1.934^{* * * *} \\
-1.679^{* *}\end{array}$ \\
\hline $\begin{array}{l}\text { lower } 95 \% \text { bound } \\
\text { upper } 95 \% \text { bound }\end{array}$ & $\begin{array}{l}100 \\
100\end{array}$ & $\begin{array}{l}-2.345^{* * *} \\
-1.697^{* *}\end{array}$ & $\begin{array}{c}-2.264^{* * *} \\
-1.511\end{array}$ & $\begin{array}{l}-2.168^{\text {*** }} \\
-1.708^{\text {** }}\end{array}$ & $\begin{array}{c}-2.000^{* * *} \\
-1.594\end{array}$ \\
\hline $\begin{array}{l}\text { lower } 95 \% \text { bound } \\
\text { upper } 95 \% \text { bound }\end{array}$ & $\begin{array}{l}50 \\
50\end{array}$ & $\begin{array}{l}-2.427^{* * *} \\
-1.613\end{array}$ & $\begin{array}{l}-2.371^{* * * *} \\
-1.469\end{array}$ & $\begin{array}{l}-2.251^{* * * *} \\
-1.629\end{array}$ & $\begin{array}{l}-2.112^{* * *} \\
-1.501\end{array}$ \\
\hline
\end{tabular}

$\left(^{*}\right),\left(^{* *}\right)$, and $\left(^{* * *}\right) 10 \%, 5 \%$, and 1\% significant (c.v. in Im, Pesaran and Shin, 1997, Table 4).

In bold: the theory-based statistic is outside the bootstrap $95 \%$ confidence interval.

$\mathrm{N}_{\mathrm{S}}\left(\mathrm{N}_{1-\mathrm{S}}\right)$ sets are defined as theory-based sub-samples homogeneously characterised by the PO (TO) behaviour 
On the contrary, results for the "high risk" (PO) sub-sample do not reject the unit root null hypothesis: if the probability and costs of financial distress are serious, firms do not issue debt to finance real investment; instead, they finance themselves by using retained earnings.

The second type of theory-based sub-sample concerns the fiscal advantage of debt and tax exhaustion (DeAngelo and Masulis, 1980). TO theory claims that a positive relationship exists between the effective corporate tax rate and the incentive to use debt: firms paying high rate taxes are likely to debt finance new investment because they can exploit a reduction in taxable income due to the deductibility of interest expenses. Results in Table 2 confirm that companies included in the "low tax exhaustion" sub-sample gain from the fiscal advantage of debt, and follow the TO model of behaviour: these firms are characterised by low non-debt tax shields (such as depreciation allowances and tax loss carry-forwards) and by high taxable income.

Clearly, companies that have been tax-exhausted in the past and have low current profits, possess no taxable income and face a zero effective corporate tax rate on interest deductions: tax loss carry-forwards, along with the availability of other non-debt tax shields, nullify the fiscal advantage of debt, i.e. one of the main TO determinants of a firm's desired leverage. Thus, the unit root tests fail to reject the null hypothesis in the "high tax exhaustion" sub-sample: the lack of any fiscal advantage of debt leads companies to behave according to the PO model.

The third type of theory-based sub-sample concerns the conflict of interests between managers and shareholders (Jensen and Meckling, 1976, Jensen, 1986). According to TO theory, if companies have free cash flow (i.e. cash flow beyond their need to finance profitable investment opportunities), managers may wish to implement unprofitable projects that increase the various monetary and non-monetary perquisites they obtain from their companies rather than company profits (the over-investment problem). Managerial conflicts of interest are particularly significant in those companies where ownership and effective control are kept separate, and dispersed shareholders have little or no incentive to monitor managers. In this case, debt forces managers to curb their empire-building tendencies: borrowing commits managers in advance to pay out the firm's free cash flow, thus avoiding wasteful investment. The results in the "high managerial agency costs" sub-sample of Table 2 confirm the prediction made by TO theory.

The PO vision of free cash flow is totally different, however. Asymmetric information leads managers to refuse external financing even if it means passing up a good investment opportunity (the under-investment problem): the cost of issuing shares and/or debt at a bargain price may outweigh the project's net present value. In order to avoid the problem, managers build up ample financial slack (e.g. large holdings of cash or marketable securities), and prefer to rely on internal sources of funds for the financing of investment opportunities. This PO behaviour is particularly 
characteristic of closely-held companies where either ownership and management are synonymous, or where a concentrated form of ownership means that shareholders can monitor management more effectively, and are more strongly motivated to do so. The alignment of interests annuls the agency costs normally accrued between managers and stockholders, thus rendering the TO problem of free cash flow irrelevant. In the "low managerial agency cost" sub-sample, we fail to reject the unit root null hypothesis: if firms have a number of profitable investment projects, their financial requirements are satisfied through internal financing in the form of both cash flow and reductions in liquid assets.

The fourth class of theory-based sub-sample concerns the conflict of interest and the asymmetric information that characterise companies and their external financiers (Jensen and Meckling, 1976, Myers, 1977, Diamond, 1991). Bank and bond debts are used by firms with different reputations and credit quality, firms that are differently motivated towards taking action which may be harmful to lenders. The "low creditors' agency costs" sub-sample in Table 2 includes TO companies: these are relatively older, more well-established firms which do not issue bonds, but permanently issue new shares, and either do not distribute earnings or pay out dividends that are lower than profits. Since these firms do not use public debt, it may be argued that they have longstanding, close ties with credit institutions. ${ }^{9}$ Thanks to their long history of repaying loans, these companies have established a reputation as good borrowers. Reputation is a positive determinant of target leverage since it reduces the problems of asymmetric information, the conflict of interest with creditors, and the cost of debt. The age and reputation of a company may stand in for economies of scales when accessing new financing; issuing shares means cheaper and easier access to capital markets; these factors speed up the adjustment of debt to its given target. Finally, dividend payment is a way of transferring wealth from lenders to shareholders: a standard debt covenant restriction specifies that the maximum allowable dividend payment is a positive function of both accounting earnings and the proceeds from the sale of new equity. Not paying dividends also exposes a company to the risk of a greater conflict of interest between managers and shareholders; in this case bank debt plays an important role in reducing managerial agency costs.

In the "high creditors' agency costs" sub-sample in Table 2 we can not reject the unit root null hypothesis. This sub-sample includes both very old and very young companies that issue public debt claims, either do not issue shares or use new equity financing only temporarily, and pay out dividends that are higher than profits. Thus, the PO prediction that firms show a hierarchical

\footnotetext{
${ }^{9}$ Moreover, these firms do not have multiple classes of debt claims outstanding which differ in dimension such as coupon, maturity and priority. Thus, there are no intra-debtholder conflicts over wealth transfers, especially during bankruptcy proceedings.
} 
preference for debt over external equity is confirmed: companies will issue equity only as a last resort, when they are not subject to asymmetric information in the capital market. Very old firms use less debt because they have other financial opportunities, such as access to public debt markets (they benefit from economies of scale in flotation costs), retained earnings and internal capital markets within the group. Very young companies display a higher degree of ex ante uncertainty concerning the value of the firm, more creditor informational asymmetries, and use less debt. Finally, paying out high dividends exacerbates any conflict of interest between lenders and borrowers (thus reducing the incentive towards debt financing). Moreover, there is no need to use debt as a means of reducing free cash flow and the discretionary power of managers: distributed earnings bring directors' behaviour in line with shareholders' wealth maximisation, and firms which pay out dividends at the same time have considerable internal funds.

\subsection{The comparison of theory-based and bootstrap IPS test results}

In theory-based sub-samples, the non-rejection of the null hypothesis in small PO subsamples could merely depend on the reduction of cross-section variability, rather than on the identification of $\mathrm{N}_{\mathrm{S}}$ homogeneous firms. In order to investigate this issue, we performed a bootstrap exercise whereby 1,000 samples of 300, 100 and 50 companies were randomly drawn from the entire set of 5,079 individual-company statistics. This gave us the bootstrap distribution of the t-bar statistics in sub-samples of similar dimensions as $\mathrm{N}_{\mathrm{S}}$ and $\mathrm{N}_{1-\mathrm{S}}$ sets. The simulated distributions were used (in Table 2) to compare the 95\% confidence intervals (obtained from the bootstrap percentiles) with exact sample critical values (from Im, Pesaran and Shin, 1997, Table 4) as well as theorybased sub-samples statistics (discussed in section 4.1).

The lower limit of the $95 \%$ bootstrap interval always $1 \%$ rejects the null hypothesis, and the upper limit statistics sometimes reject the null hypothesis too. In spite of the limited number of firms in each sample, the heterogeneity of unit root/stationarity cases in randomly-drawn companies pushes the IPS statistics towards the rejection area. As a result of an even more likely degree of heterogeneity (together with averaging effects), the null rejection of the whole bootstrap interval more frequently occurs in large samples.

The statistics from theory-based sub-samples often fall outside the $95 \%$ confidence intervals, especially in the case of PO sub-samples. The systematic increase in the t-bar statistic levels towards the non-rejection area in the PO sub-samples is due to the PO characteristics of the companies we selected, and not to the small size of the cross-section.

Among the four different theory-based types, homogeneous sub-samples are probably easier to identify using "risk" and "tax exhaustion" selection rules, since both statistics (reported in the first four rows of Table 2) fall outside the bootstrap confidence interval. On the other hand, by using 
"managerial" and "creditors" agency cost selection rules, it seems we have to leave a share (albeit small) of PO companies inside the TO sub-samples. There are two explanations for this.

Firstly, the original formulation of the static TO theory suggests that firms select an optimal capital structure by adding debt until expected bankruptcy costs ("risk") equal the tax advantage of debt ("tax exhaustion”). In other words, a firm's optimal debt-ratio is seen as being determined by the trade-off between the (distress) cost and (fiscal) benefits of borrowing, with the firm's assets and investment plans considered a constant. It is clear that the selection rules needed in order to distinguish between pure PO and TO behaviours are thus easier to identify. Extending our analysis to conflicts of interest leads to the dependency of the firm's investment policy on its capital structure. In other words, it becomes increasingly difficult to witness pure behaviour, "all other things being equal", and so we need to impose various selection rules which cannot be clearly defined on the basis of balance sheet information only. Moreover, the same "agency costs" selection rule may lead to TO or PO behaviour depending on how it is combined with the given operative conditions of companies: for example, an old firm may have a good long-standing relationship with a bank, thus limiting any conflict of interests with creditors, and stimulating TO behaviour. However, it is also true that an old - large - firm may have accumulated considerable financial slack to be used in order to behave according to the PO model, that is, to gain greater independence from the bank; this is especially true if a company does not want to disclose proprietary information about corporate strategies that may benefit its competitors.

Secondly, failure and taxation characteristics are more stable over time. For example, stocks of different types of assets (usually interpreted as proxies for distress costs), as well as corporate tax rates, remain constant for long periods. Thus the target leverage which depends on these characteristics may be considered stable over time as well, leading to a clear identification of TO behaviour. On the contrary, "agency costs" sub-samples are selected on the basis of firms' peculiarities, such as operative income and growth opportunities, which tend to change more frequently. In this case, a univariate form of analysis makes it more difficult to decide whether an optimal level of leverage, which changes over time in response to changes in its determinants, does in fact exist (a possibility of TO theory), or whether a target debt-ratio does not exist and a company issues debt only if external financing is needed (as envisaged by PO theory).

\section{Conclusions}

There is considerable interest in theoretical corporate financing models, as is shown by the number of works written about this issue. On the methodological side, unit root $v s$ stationarity testing procedures has also received considerable attention from theorists and practitioners alike. The present paper attempts to find new evidence regarding corporate finance. Our results are based 
on a dataset of 5,079 Italian manufacturing companies covering the period 1982-1995. Our empirical analysis is sub-divided into three parts, the results of which can be summarised as follows.

The single-company test outcomes are largely in line with the PO prediction: in about $80 \%$ of the cases, the null hypothesis of debt-ratio integration is not $10 \%$ rejected. Only a small number of the firms in the sample revert to a constant target debt-ratio. However, apparent non-stationarity can sometimes be induced either by low power, or by possible changes in the target debt-ratio levels.

The cross-section variability introduced at panel level increases power, and in our case enables us to clearly reject the unit root null hypothesis. However, the companies in the panel can not be labelled as "pure" TO followers, since the alternative hypothesis of the IPS test allows for both TO and PO cases.

Since the potentially false presumption of behavioural homogeneity under the null hypothesis may induce us to reject the unit root hypothesis, we made inferences from sub-samples, chosen on theoretical grounds in order to increase homogeneity. The test results, in keeping with theoretical predictions, suggest that theoretical insights can help identify those companies that behave in the same way with regard to their financial decisions. A bootstrap exercise, where subsamples are randomly drawn from the whole dataset, reinforces the idea that theoretically-based sub-sample results are due to the homogeneity of financial behaviour, rather than to reduced sample size.

Overall, previous results would seem to point to two general conclusions. Firstly, since pure PO behaviour can be only found in specific sub-samples, a certain percentage of Italian firms adjusts towards a target debt-ratio. This finding is in keeping with the results reported in Bontempi (2001): the best way of defining the financial behaviour of Italian manufacturing firms is to formulate models where both PO and TO components are admissible.

Secondly, by using the panel unit root test we can only reject the pure pecking order model of behaviour, but not the pure trade-off model. Shyam-Sunder and Myers (1999) claim that "empirical work on capital structure must devise tests of hypotheses that can be rejected" (p. 243), and find that "the statistical power of some usual tests of the TO model is virtually nil" (p. 219). In a similar manner, the different testing procedure we propose has the power to reject the pure pecking order model under the null hypothesis, but not the pure trade-off one.

\section{References}

Banerjee A., M. Marcellino and C. Osbat (2001), Testing for PPP: should we use panel methods?, mimeo, January 
Bontempi M.E. (2001), The dynamic specification of the modified pecking order theory: its relevance to Italy, Empirical Economics, forthcoming

Bradley M., G.A. Jarrell and E.H. Kim (1984), On the existence of an ottimal capital structure: theory and evidence, Journal of Finance, 39(3), 857-880

Castanias R. (1983), Bankruptcy risk and optimal capital structure, Journal of Finance, 38, 5, $1617-1635$

Cecchetti S.G., N.C. Mark and R.J. Sonora (2000), Price level convergence among United States cities: lessons for the European Central Bank, NBER W.P. 7681

Culver S.E. and D.H. Papell (1997), Is there a unit root in the inflation rate? Evidence from sequential break and panel data models, Journal of Applied Econometrics, 12, 435-444

DeAngelo H. and R.W. Masulis (1980), Optimal capital structure under corporate and personal taxation, Journal of Financial Economics, 8, 1, 3-29.

Diamond D.W. (1991), Monitoring and reputation: the choice between bank loans and directly placed debt, Journal of Political Economy, 99, 4, 689-721.

Dickey D.A. and W.A. Fuller (1979), Distribution of the estimators for autoregressive time series with a unit root, Journal of American Statistical Association, 74, 427-431

Frankel J.A. and A.K. Rose (1996), A panel project on PPP: mean reversion within and between countries, Journal of International Economics, 40, 209-224

Granger C.W.J. and P. Newbold (1974), Spurious regression in econometrics, Journal of Econometrics, 2, 111-120

Hadri K. (2000), Testing for stationarity in heterogeneous panel data, Econometrics Journal, 3, 148-161

Hakkio C.S. (1984), A re-examination of purchasing power parity, a multi-country and multiperiod study, Journal of International Economics, 17, 265-277

Hakkio C.S. and M. Rush (1991), Cointegration: how long is the long run?, Journal of International Money and Finance, 10, 571-581

Harris M. and A. Raviv (1991), The theory of capital structure, Journal of Finance, 46, 297-355.

Higgins M. and E. Zakrajsek (1999), Purchasing Power Parity: three stakes through the heart of the unit root null, Federal Reserve of New York, Staff Reports, 80, June

Im K.S., H.M. Pesaran and Y. Shin (1997), Testing for unit roots in heterogeneous panels, Trinity College, Cambridge

Jalilvand A. and R.S. Harris (1984), Corporate behaviour in adjusting to capital structure and dividends targets: An econometric study, Journal of Finance, 39, 1, 127-145

Jensen M.C. (1986), Agency costs of free cash flow, corporate finance, and takeovers, American Economic Review, Papers and Proceedings, 76, 2, 323-329

Jensen M.C. and W.M. Meckling (1976), Theory of the firm: managerial behavior, agency costs, and ownership structure, Journal of Financial Economics, 3, 305-360

Karlsson S. and M. Lothgren (2000), On the power and interpretation of panel unit root tests, Economics Letters, 66, 249-255

King R.G., C.I. Plosser, S.H. Stock and M.W. Watson (1991), Stochastic trends and economic fluctuations, American Economic Review, 81, 819-840

León-Ledesma M.A. (2000), Unemployment hysteresis in the US and the EU: a panel data approach, Studies in Economics, Department of Economics, University of Kent

Levin A. and C.F. Lin (1992), Unit root tests in panel data: asymptotic and finite-sample properties, University of California, San Diego, Discussion Paper, 93, May

Levin A. and C.F. Lin (1993), Unit root tests in panel data: new results, University of California, San Diego, Discussion Paper, 56, December

MacDonald R. (1996), Panel unit root tests and real exchange rates, Economics Letters, 50, 7-11

MacKinnon J.G. (1991), Critical values for cointegration tests, R.F. Engle and C.W.J. Granger (eds.), Long Run Economic Relationships: Readings in Contegration, Chapter 13, Oxford University Press, Oxford 
Maddala G.S. and S. Wu (1999), A comparative study of unit root tests with panel data and a new simple test, Oxford Bulletin of Economics and Statistics, 61(4), 631-652

Marsh P.R. (1982), The choice between equity and debt: an empirical study, Journal of Finance, $37,1,121-44$.

Myers S.C. (1977), Determinants of corporate borrowing, Journal of Financial Economics, 2, 147175.

Myers S.C. and N.S. Majluf (1984), Corporate financing and investment decisions when firms have information that investors do not have, Journal of Financial Economics, 13, 187-221

Nelson C.R. and C.I. Plosser (1982), Trends and random walks in macroeconomic time series: some evidence and implications, Journal of Monetary Economics, 10, 139-162

O'Connell P. (1998), The overvaluation of PPP, Journal of International Economics, 44, 1-19

Oh K.Y. (1996), PPP and unit root tests using panel data, Journal of International Money and Finance, 15, 405-418

Opler T. and S. Titman (1997), The debt equity choice, Fisher College of Business, Ohio State University, Columbia, mimeo

Papell D.H. (1997), Searching for stationarity: PPP under the current float, Journal of International Economics, 43, 313-332

Shyam-Sunder L. and S.C. Myers (1999), Testing static trade off against pecking order models of capital structure, Journal of Financial Economics, 51, 219-244

Song F.M. and Y. Wu (1997), Hysteresis in unemployment: evidence from 48 US states, Economic Inquiry, XXXV, April, 235-243

Strauss J. (2000), Is there a permanent component in US real GDP, Economics Letters, 66, 137-142

Taggart R.A. (1977), A model of corporate financing decisions, Journal of Finance, 32(5), 1467-84

Taylor M. and L. Sarno (1998), The behaviour of real exchange rates during the post Bretton Woods period, Journal of International Economics, 46, 281-312

Wu J.-L. (2000), Mean reversion of the current account: evidence from the panel data unit root test, Economics Letters, 66, 215-222

Wu Y. (1996), Are real exchange rates stationary? Evidence from panel data test, Journal of Money, Credit and Banking, 28, 54-63

$\mathrm{Wu}$ Y. and H. Zhang (1996), Mean reversion in interest rates: new evidence from a panel of OECD countries, Journal of Money, Credit and Banking, 28, 604-621

\section{Appendix: The definition of the theory-based sub-samples}

Table A.1 illustrates the selection rules adopted when defining the four types of theorybased sub-samples. The variables used are both discrete and continuous. Discrete variables indicate whether a particular condition does in fact exist during the sample period. Continuous variables are transformed into historical means and then categorised using seven quantiles, Q1, Q2, .., Q7, which respectively indicate the 12.5 th, 25th,..., 87.5th percentiles; Q4 corresponds to the 50th percentile or median. The choice of a greater number of quantiles than are usually chosen (three is the standard number) allows for the more flexible classification of companies: it enables to identify extreme PO and TO characteristics, while at the same time preserving the general information contained in the quartiles. Finally, all the results obtained in the four types of theory-based sub-samples are confirmed using various check rules, as illustrated in the second part of Table A.1, which are added 
to and/or replace the selection rules adopted ${ }^{10}$. From the theoretical point of view, such check rules allow for a further verification of our capacity to select homogeneous PO- and TO-type companies on the basis of the given firms' attributes as indicated by financial theory. From the empirical point of view, as check rules modify the absolute and relative size of theory-based sub-samples, they also offer further evidence that our results do not merely depend on the reduction in the variability of the cross-section.

The "risk" type theory-based sub-samples are selected by combining indicators of interest volatility, guarantees and capital intensity. Investment in intangible assets is added as a check rule.

1. Interest volatility is measured by comparing the firm's standard deviation in total interest charges with the firm's standard deviation in earnings before interest expenses are deducted. In the "high (low) risk" sub-sample this ratio is greater (equal to or smaller) than one, indicating a higher (lower) likelihood of financial distress.

2. Guarantees are measured by a dummy variable indicating whether companies have mortgages, pawns, pledges and warrants granted by other firms, affiliates or banks during the sample period. "High (low) risk" firms never have guarantees during the sample period (have guarantees for at least one year during the sample period).

3. Capital intensity is measured by the ratio of real sales ${ }^{11}$ to the number of employees. "High (low) risk" companies are labour (capital) intensive, i.e. their ratios are lower (higher) than the 87.5th percentile. The lower capital intensity is, the smaller tangible assets and liquidation values are.

4. Findings regarding "risk" sub-samples are confirmed by adding a check rule which measures how long companies invest in intangible assets: a firm's liquidation value is lower if it derives more from future and specialised projects than from tangible assets-in-place. The check rule is a dummy variable indicating whether or not companies invest in intangible assets for more than one year during the sample period. In the case of repeated investment in intangible assets, the "high risk" sub-sample includes 102 companies behaving according to the PO model because such projects are risky, more subject to asymmetric information and difficult to finance externally. On the contrary, the "low risk" sub-sample of companies not investing, or investing for one year only, in intangible assets ( 8 firms), is characterised by the relatively lower cost of failure and a more evident TO form of behaviour.

\footnotetext{
${ }^{10}$ The results of the t-bar tests in these sub-samples are not given, but they are available upon request from the authors.

${ }^{11}$ Deflated by the production price indexes of the 13 sub-sectors of manufacturing industry reported by the Italian Central Statistical Office, ISTAT.
} 
The "tax exhaustion" type theory-based sub-samples are selected according to past tax exhaustion status and past non-debt and interest tax-shields with respect to current profits. The check rule selects certain firms according to the duration of their tax exhaustion status.

1. Tax exhaustion is measured using a categorical variable: this equals 0 in the case of firms with lagged pre-tax earnings that are constantly positive during the sample period; 1 if lagged pre-tax earnings were negative or zero for a period from 1 to 5 years; 2 if lagged pre-tax earnings were negative or zero for more than 5 years ${ }^{12}$. In the "high (low) tax exhaustion" sub-sample this categorical variable is equal to $1(0)$, and companies have large (small) tax loss carry-forwards that can be used in order to reduce current taxable income.

2. Non-debt tax shields are measured by the ratio of lagged level of tangible and intangible depreciation allowances and total assets. In the "high (low) tax exhaustion" sub-sample nondebt tax shields are above the 62.5th (below the 50th) percentile.

3. The fiscal advantage of debt is measured by the effective lagged interest rates paid, net of the statutory corporate tax rate if companies were not tax exhausted. The effective interest rates are given by the ratio of interest charges on bank and quasi-bank debt (leasing, factoring, etc.) and the corresponding debt. In the "high (low) tax exhaustion" sub-sample, effective interest rates are below the 50th (above the 62.5th) percentile.

4. Net earnings in real terms ${ }^{13}$ account for the relevance of non-debt and interest tax shields in exhausting current taxable income and reducing the effective tax rate on the basis of which the fiscal advantage of debt is computed. Companies included in the "high (low) tax exhaustion" sub-sample have low (high) current profits, i.e. below the 50th (above the 62.5th) percentile.

5. According to TO theory, the lower taxable income and effective corporate tax rate are, the lower desired leverage is. Thus, the check rule selects 62 "low tax exhaustion" firms that have been tax-exhausted for a period of 1 to 5 years, and 58 "high tax exhaustion" companies that have been in loss for more than 5 years. The unit root null hypothesis is still rejected in the first case: even though these companies, having been tax-exhausted in the past, can exploit the tax loss carry-forwards in order to reduce taxable income, they still gain from the fiscal advantage of debt. Conversely, the unit root null hypothesis is not rejected in the second case: due to the relevance of tax loss carry-forwards, these companies have low current profits and thus cannot deduce interest expenses.

\footnotetext{
12 This classification is due to the possibility loss-making Italian companies have of carrying forward past losses for a period of up to five years.

${ }^{13}$ Deflated by the production price indexes of the 13 sub-sectors of manufacturing industry reported by ISTAT.
} 
The "managerial agency costs" type theory-based sub-samples are selected by combining indicators of previous cash flow, current investment opportunities and profitability, size and corporate ownership. The check rule uses group-membership condition in place of the ownership structure selection rule.

1. Cash flow is calculated from lagged operative earnings before depreciation, non-operative and extraordinary items, and other non-cash expenses ${ }^{14}$; it is net of total interest expenses and dividends paid, and is expressed in terms of net assets. In the "low (high) managerial agency costs" sub-sample, cash flow is below (equal to or above) the 75th percentile.

2. Investment opportunities are given by the sum of net investment in plant, equipment and $R \& D$, and the variation in net working capital, as a percentage of total net assets. Net working capital is defined as current assets (chiefly accounts receivable, inventories and cash) less current liabilities (accounts payable, accruals, deferred taxes, investment tax credits, and minority interests). Investment opportunities represent the total financing requirements of the firm, which can be satisfied by building up debt or equity accounts through stock issuance, or by using internal financing in the form of cash flow. The variation in net working capital indicates the extent to which firms drawn upon liquid assets in order to finance investment needs, or the degree to which they choose to invest in liquid assets in order to build up financial slack to be used at a later date; thus, the effect of free cash flow on new debt only emerges when we check for changes in working capital. In the "low (high) managerial agency costs" sub-sample, investment opportunities are equal to or above (below) the 62.5 th percentile.

3. Investment profitability is proxied by the ratio of sales to gross investment, both tangible and intangible. In the "low (high) managerial agency costs" sub-sample, investment profitability is equal to or above (below) the 75th percentile.

4. Size is measured in terms of the number of employees during the sample period. The "low (high) managerial agency costs" sub-sample includes medium-large (small-medium) companies which have more than 50 (from 0 to 249) employees.

5. Corporate ownership is measured by a dummy variable equal to 1 if the first shareholder holds more than $50 \%$ of total shares issued. Since managerial agency costs result from the separation of ownership (residual risk bearing function) and control (decision function), one way of controlling them is by restricting the ownership on residual claims ${ }^{15}$ to one major agent who

\footnotetext{
${ }^{14}$ Since the Continental European accounting system allows companies to smooth out profits using hidden reserves, this adjusted measure of book earnings avoids the undesired effects of window dressing by some firms.

15 Claims to the net cash flows that result from differences between inflows and promised payments to other claimholders.
} 
bears the wealth effects of his decisions. Thus, in the "low (high) managerial agency costs" subsample, ownership is concentrated (widespread).

6. Concentrated ownership is more common than the more dispersed form in large Italian companies, since they generally belong to pyramidal business groups, and this enables the ultimate owner to control the firm's assets using the least amount of capital. As a check rule, we substitute the group-membership condition for the ownership selection rule. This does not change the PO test result obtained for "low managerial agency costs" (119 firms). The overinvestment problem due to a managerial conflict of interests is thus limited without creating a sub-investment problem due to imperfections in the credit market; this is because a group offers a company both credit from affiliates (controlled, linked and controlling firms) as well as other financial funds from the internal capital markets. The TO test result confirms the role of debt in reducing managerial agency costs for those 303 companies characterised by "high managerial agency costs", an unconditioned ownership structure and non-membership of a pyramidal group.

Tab. A.1 - Definition of theory-based sub-samples

\begin{tabular}{|c|c|c|c|c|c|c|c|c|}
\hline \multirow[t]{2}{*}{ Selection rules } & \multicolumn{2}{|c|}{ risk } & \multicolumn{2}{|c|}{ tax exhaustion } & \multicolumn{2}{|c|}{ managerial agency costs } & \multicolumn{2}{|c|}{ creditors' agency costs } \\
\hline & high & low & high & low & low & high & high & low \\
\hline Interest volatility & $>1$ & 1 & & & & & & \\
\hline Guarantees & no & yes & & & & & & \\
\hline Capital intensity & $<\mathrm{Q} 7$ & $>\mathrm{Q} 7$ & & & & & & \\
\hline Tax exhaustion & & & $1-5$ years & never & & & & \\
\hline Non-debt tax shields & & & $>\mathrm{Q} 5$ & $<\mathrm{Q} 4$ & & & & \\
\hline Fiscal adv. of debt & & & $<\mathrm{Q} 4$ & $>\mathrm{Q} 5$ & & & & \\
\hline Net earnings & & & $<\mathrm{Q} 4$ & $>\mathrm{Q} 5$ & & & & \\
\hline Cash flow & & & & & $<$ Q6 & Q6 & & \\
\hline Inv. opportunities & & & & & Q5 & $<\mathrm{Q} 5$ & & \\
\hline Inv. profitability & & & & & Q6 & $<\mathrm{Q} 6$ & & \\
\hline Size & & & & & $\begin{array}{l}\text { medium- } \\
\text { large }\end{array}$ & $\begin{array}{l}\text { small- } \\
\text { medium }\end{array}$ & & \\
\hline Ownership & & & & & concentrated & diffused & & \\
\hline Age & & & & & & & old or young & middle \\
\hline Issue of new shares & & & & & & & $\begin{array}{c}\text { no or 1-4 } \\
\text { years }\end{array}$ & $>4$ years \\
\hline Issue of new bonds & & & & & & & yes & no \\
\hline Dividend payments & & & & & & & profits & no or < profits \\
\hline \multicolumn{9}{|l|}{ Check rules } \\
\hline $\begin{array}{l}\text { Intangible inv. } \\
\text { Tax exhaustion }\end{array}$ & $>1$ year & 1 year & $>5$ years & $1-5$ years & & & & \\
\hline Group & & & & & yes & no & & \\
\hline Mergers & & & & & & & yes & no \\
\hline
\end{tabular}

The "creditors' agency costs" type theory-based sub-samples are selected by taking into consideration indicators of age, the issuing of bonds and shares on the capital markets, and the paying of dividends. The check rule replaces the payout selection rule in extraordinary operations such as mergers. 
1. The "high (low) creditors' agency costs" sub-sample includes old-young (average-age) companies, founded either before the 1950s or after the 1970s (between the 50s-70s). Old - and very large - firms use less bank debt because they can borrow both in public capital markets and in internal capital markets (inside the pyramidal group); young firms probably use less debt because they have not had time to build up a reputation, and are characterised by a higher degree of ex-ante uncertainty about the value of the firm and more creditor informational asymmetries. Average-aged firms generally have established reputations as good borrowers.

2. Since our firms are not listed and do not go public, the extent to which they may be financed by external equity (bonds) is measured by the change in common and preferred stocks (bonds). With regard to the issue of new bonds and shares, the dummy variables classify PO and TOtypes as follows: the "high creditors' agency costs" sub-sample does not use new equity financing, or uses it for a short period (from 1 to 4 years), whereas it uses public debt financing in the form of bonds; the "low creditors' agency costs" sub-sample makes extensive use of new equity financing (for more than 4 years), but does not borrow on the capital market in the form of bonds.

3. Companies in the "high creditors' agency costs" sub-sample pay out dividends that are higher than profits. Companies in the "low creditors' agency costs" sub-sample either do not distribute earnings or pay out dividends that are lower than profits.

4. PO unit root test results do not change if we replace the dividend selection rule with a check rule regarding extraordinary operations such as take-overs (120 companies): if inefficient managerial behaviour increases the risk that the firm will be acquired by another company, directors are more likely to seek market value maximisation. Moreover, this fact may be seen as a check of possible sample bias deriving from the fact that mergers may produce significant changes in a firm's financial structure and accounting statements. Without such screens, the balance sheet data may give us a distorted view of a firm's normal financing behaviour over time. Despite the existence of other possible reasons behind mergers, results seem to support the PO hypothesis that a merger is also a way of acquiring more financial slack, especially if the buyer is cashflow-rich and the taken-over company offers good investment opportunities. TO unit root results do not change if we replace the dividend-payment selection rule with a check rule regarding the non-performance of extraordinary operations (447 companies). This may be ascribed to the fact that such complex operations may make it easier for firms to deceive the bank about the true state of the company, its actual guarantees and future projects, thus creating a greater conflict of interests with lenders. 